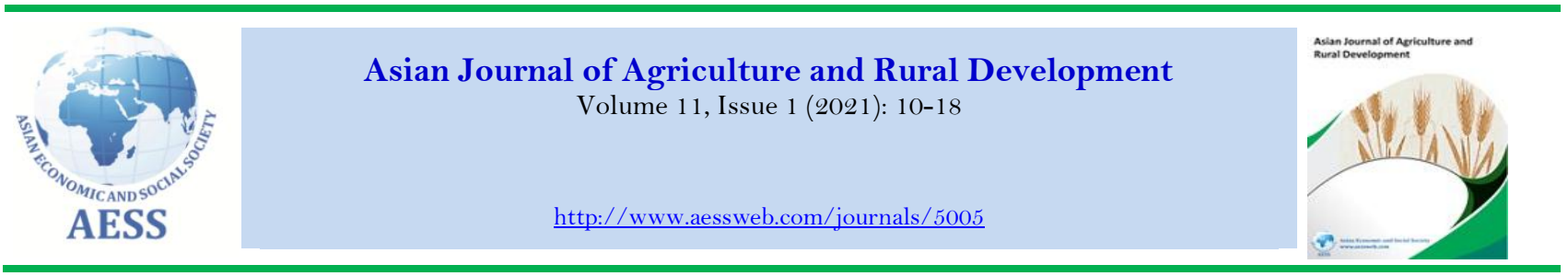

\title{
EFFECTS OF MORINGA LEAF EXTRACT AND POULTRY MANURE ON THE GROWTH PARAMETERS OF SWEET MAIZE
}

\author{
Alubiagba, D. O. ${ }^{\mathrm{a}}$ \\ Ovharhe, O. J. ${ }^{\text {b }}$ \\ Akparobi, S. O.
}

\author{
a, Department of Agronomy, Forestry and Wild Life Delta State University, Asaba \\ Campus, Asaba, Delta State, Nigeria. \\ ${ }^{b}$ Department of Agricultural Economics and Extension Delta State University, Asaba \\ Campus, Asaba, Delta State, Nigeria.
}

هhaolindave@yahoo.com (Correspondingauthor)

\section{Article History}

Received: 23 October 2020

Revised: 27 November 2020

Accepted: 21 December 2020

Published: 18 January 2021

\section{Keywords}

Sweet maize

Poultry manure

Moringa leaf extract

Leaf area

Growth

Extension workers.

\begin{abstract}
This study examined the effects of moringa leaf extract (MLE) and poultry manure (PM) on the growth parameters of sweet maize. The experiment was a Randomized Complete Block Design involving nine treatments: control (no extract), 3\% MLE, 6\% MLE, 9\% MLE, 3\% MLE + $15 \mathrm{t} / \mathrm{ha}^{-1} \mathrm{PM}, 6 \%$ MLE +15 t/ha ${ }^{-1}$ PM, 9\% MLE + 15 t/ha ha $^{-1}$ PM, 15 t/ha- ${ }^{-1}$ PM, and 30 t/ha ${ }^{-1}$ PM. Data on growth parameters including plant height, number of leaves per plant, stem girth, and leaf area were collected and analyzed. The results of the study show that there were significant differences $(P=0.05)$ among the treatments because plots that received $30 \mathrm{t} / \mathrm{ha}^{-1} \mathrm{PM}$ performed best on plant height (193.6 and $152.8 \mathrm{~cm})$ number of leaves (13.1 and 10.2), stem girth $(3.75$ and $3.22 \mathrm{~cm})$, and leaf area $\left(584.9\right.$ and $\left.402.9 \mathrm{~cm}^{2}\right)$ in both early and late season. This was followed by plots that received $9 \%$ MLE and $15 \mathrm{t} / \mathrm{ha}^{-1} \mathrm{PM}$, with values of 189.0 and $152.2 \mathrm{~cm} ; 12.5$ and $10.0 ; 3.583 .15 \mathrm{~cm}$; and 546.2 and $392.2 \mathrm{~cm}^{2}$, respectively. The study concluded that $30 \mathrm{t} / \mathrm{ha}^{-1} \mathrm{PM}$ can be used to yield effective growth parameters in sweet maize and is hereby recommended to extension workers for dissemination to farmers
\end{abstract}

Contribution/Originality: This study is one of very few studies to have investigated the effects of Moringa oleifera extract on field crops in Delta state, Nigeria. In combination with poultry manure, moringa extract shows great promise in improving the growth characteristics of sweet maize, a major vegetable crop.

DOI: 10.18488/journal.ajard.2021.111.10.18

$\operatorname{ISSN}(\mathrm{P}):$ 2304-1455/ ISSN(E): $2224-4433$

How to cite: Alubiagba, D. O. --- Ovharhe, O. J. --- Akparobi, S. O. (2021). Effects of Moringa Leaf Extract and Poultry Manure on the Growth Parameters of Sweet Maize. Asian Journal of Agriculture and Rural Development, 11(1), 10-18. 10.18488/journal.ajard.2021.111.10.18 (C) 2021 Asian Economic and Social Society. All rights reserved.

\section{INTRODUCTION}

Sweetcorn (Zea mays var. saccharata) is a maize variety with tender, delicious sugar kernels eaten as a vegetable. In contrast to traditional field corn, sweetcorn varieties are harvested when the kernels have just reached the milk stage and are used earlier. Sweetcorn has achieved major commercial success in many tropical and subtropical countries (Okonmah \& Eruotor, 2012). The commercial success of maize crops notwithstanding, production in Nigeria has been bedevilled by low yields due to factors such as low soil fertility and negligence regarding soil amendment materials (DIPA, 2006; Enujeke, 2013). While manures and fertilizers are indispensable for increased crop productivity, Phiri (2010) noted that dependence on the use of inorganic fertilizers is associated with land and soil degradation, as well as environmental pollution (Anyaegbu, 2015).

In recent years, there is increasing awareness among maize farmers of the benefits of organic fertilizer application. This is because organic fertilizers not only increase physical soil properties such as porosity, structure, 
water-holding capacity, and chemical balance, but also increase mineral deposition, which is essential for the proper development of plants (Amujoyegbe, Opabode, \& Olayinka, 2007; Mishra, Singh, Singh, Das, \& Prasad, 2013).

Makkar, Francis, and Becker (2007) found that moringa leaf extract (MLE) contains significant quantities of calcium, potassium, and cytokinin in the form of zeatin, antioxidants, proteins, ascorbates, and phenols. Fresh moringa leaves sampled from various parts of the world were found to have high leaf zeatin concentrations of between 5 and $200 \mathrm{mcg} / \mathrm{g}$.

Phiri (2010) and Yasmeen, Basra, Ahmad, and Wahid (2012) have reported that MLE is an excellent seedpriming agent for stress-grown wheat and that it enhanced the germination of sorghum, the length of maize radicles, and the hypocotyls of wheat, thereby affecting cereal germination and establishment. Phiri and Mbewe (2010) have also observed that MLE increased the duration of the first germination of beans and increased the germination percentage of cowpea, but caused reduced germination percentage in groundnut and overall lower seedling survival in all three legumes, thereby leading to the postulation that MLE should not be used as a priming agent for legumes due to the presence of inhibitory substances absorbed through the various seed coats.

Besides the contribution of MLE and poultry manure (PM) to vegetative growth phase, there is a need to guide farmers in regard to the useful and appropriate quantities of MLE and PM to apply from one farm location to another. Hence, this study is a useful guide to determining the effectiveness and application rates of MLE and PM in the study area. The specific aim of the study was to examine the effects of moringa (Moringa oleifera Lam.) leaf extract and PM on the growth parameters of sweetcorn.

\section{MATERIALS AND METHODS}

A field study was carried out from August to November 2018 and April to July 2019 at the Research and Teaching Farms, Department of Agronomy, Delta State University, Asaba Campus, while the analysis was done at the Animal and Environmental Biology Laboratory of Delta State University, Abraka. The experimental site is located at latitude $06^{\circ} 14^{\prime} \mathrm{N}$ and longitude $06^{\circ} 49^{\prime} \mathrm{E}$. Seeds of sweetcorn $\mathrm{TZ}$ varieties were procured from the International Institute of Tropical Agriculture (IITA), Ibadan, Oyo State, while moringa was locally sourced from the study area. Moringa leaves were oven dried and analyzed for their nutrient contents, including total nitrogen (Ryan, Estefan, \& Rashid, 2001), phosphorus, potassium, calcium, magnesium, copper, iron, manganese, and zinc (Bingham, 1982; Ryan et al., 2001). MLE was prepared using the method of Price (2007) by grinding young shoots (leaves and tender branches) with water $(1 \mathrm{l} / 10 \mathrm{~kg}$ fresh material) in a blender for $15 \mathrm{~min}$ and then filtering the homogenized solution through no. 2 Whatman filter paper. This was then proportionally diluted with water to obtain 3,6 , and $9 \%$ concentration levels for the various treatments.

Preplanting soil analysis: soil samples were randomly collected from the 0-15-cm layer of the experimental plot using a soil auger. The samples were sieved of stones, roots, and leaves before being air-dried at room temperature for three days and pulverized using a porcelain mortar and pestle. The crushed samples were then sieved using a 2mm-aperture sieve and analyzed. Particle size distribution was determined by the hydrometer method (Gee \& Baudee, 1986) after destroying the organic matter with hydrogen peroxide and dispersing the soil with $0.5 \mathrm{~N}$ sodium hexameta phosphates, while soil $\mathrm{pH}$ was measured using a Pyeunican model MK2 $\mathrm{pH}$ meter in a 1:2.5 soil:water suspension ratio. Organic carbon was determined by the Walkey-Black wet oxidation method (Nelson \& Sommers, 1982). Total nitrogen was evaluated by the micro-Kjeldahl distillation technique as described by Breminer and Mulvaney (1982). Available phosphorus was measured by the Bray No. 1 method (IITA International Institute of Tropical Agriculture, 1979), while exchangeable potassium (K), calcium (Ca), magnesium $(\mathrm{Mg})$, and sodium (Na) were determined by flame photometry (Chapman, 1965). Cation exchange capacity (CEC) was evaluated by the ammonium acetate saturation method (Roades, 1982). The chemical components of PM used for the experiment were also analyzed in order to ascertain their nutrient composition. Field procedure: The study was carried out as a split plot in a randomized complete block design (RCBD), with three replicates. Plots measuring $3.0 \times 1.5 \mathrm{~m}^{2}$ were prepared on a land area measuring $663.0 \mathrm{~m}^{2}$ selected for the study and prepared manually by clearing with hoe and machete, then marked out using a basin formation according to the experimental layout. Improved sweetcorn seeds of the TZ variety obtained from IITA were sown on the plots at the rate of three seeds per hole at a depth of $2-3 \mathrm{~cm}$, with $75 \times 25 \mathrm{~cm}^{2}$ spacing. At 3 weeks after planting (WAP), the maize crop was thinned to one plant per stand leaving the most vigorous seedlings, to give a plant population density of 53,333/ha. Weeding was done manually three times using a hoe at the $3^{\text {rd }}, 6^{\text {th }}$, and $9^{\text {th }}$ weeks after sowing.

\subsection{Treatment Protocol} where

Nine treatments were involved: $\mathrm{T}_{1}, \mathrm{~T}_{2} \ldots \mathrm{T}_{9}$

$\begin{array}{lll}\mathrm{T}_{1} & = & \text { Control (no extract or PM) } \\ \mathrm{T}_{2} & = & 3 \% \mathrm{MLE} \\ \mathrm{T}_{3} & = & 6 \% \mathrm{MLE} \\ \mathrm{T}_{4} & = & 9 \% \mathrm{MLE} \\ \mathrm{T}_{5} & = & 3 \% \mathrm{MLE}+15 \mathrm{t} / \mathrm{ha}^{-1} \mathrm{PM} \\ \mathrm{T}_{6} & = & 6 \% \mathrm{MLE}+15 \mathrm{t} / \mathrm{ha}^{-1} \mathrm{PM} \\ \mathrm{T}_{7} & = & 9 \% \mathrm{MLE}+15 \mathrm{t} / \mathrm{ha}^{-1} \mathrm{PM} \\ \mathrm{T}_{8} & = & 15 \mathrm{t} / \mathrm{ha}^{-1} \mathrm{PM} \\ \mathrm{T}_{9} & = & 30 \mathrm{t} / \mathrm{ha}^{-1} \mathrm{PM}\end{array}$


MLE was applied at 2, 4, 6, and 8 WAP by foliar application, spraying the entire plants in the designated study plots using a knapsack sprayer. The parameters listed henceforth were obtained from the innermost ten plants of each study plot.

The growth parameters measured were plant height, number of leaves, stem girth, and leaf area. Plant height was measured to the nearest centimeter using a measuring tape, from the base to the highest growing point, i.e., the leaf sheath of the last fully opened leaf. The number of leaves was determined by counting the number of fully opened leaves, starting from the base of the plant upwards. Stem girth was measured at the base of the plant with the aid of Vernier calipers, to the nearest millimeter. Leaf area was measured by tape using the non-destructive analysis method: length x width x 0.75, according to Duke and Dulelar as reported by Enujeke (2013), i.e., LA $\left(\mathrm{cm}^{2}\right)=0.75 \mathrm{x}$ $\mathrm{L} \times \mathrm{W}$

\subsection{Statistical Analysis}

Data collected were subjected to analysis of variance (ANOVA) and means were separated using the Duncan multiple range test (DMRT) at the $5 \%$ level of significance.

\section{RESULTS AND DISCUSSION}

\subsection{Chemical Composition of Leaves.}

The results of the proximate analysis of $M$. oleifera leaves used in the study are shown in Table 1 . These show that, per $100 \mathrm{~g}$, moringa leaves contained $10.51 \mathrm{~g}$ moisture, 86.2 calories, $21.95 \mathrm{~g}$ protein, $2.64 \mathrm{~g}$ fat, $49.31 \mathrm{~g}$ carbohydrate, $9.83 \mathrm{~g}$ fibre, $5.76 \mathrm{~g}$ ash, $4.0 \mathrm{~g}$ calcium, $0.08 \mathrm{mg}$ copper, $18.7 \mathrm{mg}$ iron, $22.25 \mathrm{mg}$ potassium, $5.0 \mathrm{mg}$ phosphorus, and $0.02 \mathrm{mg}$ sulphur.

Table 1. Chemical composition of M. oleifera leaves/ $100 \mathrm{~g}$

\begin{tabular}{l|c}
\hline Component & Value \\
\hline Moisture $(\mathrm{g})$ & 10.51 \\
\hline Calories $(n)$ & 86.2 \\
\hline Protein $(\mathrm{g})$ & 21.95 \\
\hline Fat $(\mathrm{g})$ & 2.64 \\
\hline Carbohydrate $(\mathrm{g})$ & 49.31 \\
\hline Fibre $(\mathrm{g})$ & 9.83 \\
Ash $(\mathrm{g})$ & 5.76 \\
\hline Calcium $(\mathrm{mg})$ & 4.0 \\
\hline Copper $(\mathrm{mg})$ & 0.08 \\
\hline Iron $(\mathrm{mg})$ & 18.7 \\
\hline Potassium $(\mathrm{mg})$ & 22.25 \\
\hline Magnesium $(\mathrm{mg})$ & 45.0 \\
\hline Phosphorus $(\mathrm{mg})$ & 5.0 \\
\hline Sulphur $(\mathrm{mg})$ & 0.02 \\
\hline
\end{tabular}

\subsection{Chemical Composition of PM}

The chemical composition of PM used in the study is shown in Table 2. Analysis shows that it contained 0.61 ppm magnesium, 1.48 ppm calcium, 0.29 ppm sodium, 1.18 ppm phosphorus, $2.67 \%$ nitrogen, 0.74 ppm potassium, $1.20 \%$ organic carbon, $2.57 \%$ organic matter, and the $\mathrm{C}: \mathrm{N}$ ratio was 0.45 .

Table 2. Chemical composition of PM

\begin{tabular}{l|c}
\hline Element & Value \\
\hline Magnesium (ppm) & 0.61 \\
\hline Calcium (ppm) & 1.48 \\
\hline Sodium (ppm) & 0.29 \\
\hline Phosphorus (ppm) & 1.18 \\
\hline Nitrogen (\%) & 2.67 \\
\hline Potassium (ppm) & 074 \\
\hline Organic carbon $(\%)$ & 1.20 \\
\hline Organic matter $(\%)$ & 2.57 \\
\hline C:N ratio & 0.45 \\
\hline
\end{tabular}

\subsection{Effects of MLE and PM on Plants \\ 3.3.1. Height}

The response of plant height to MLE and PM is shown in Table 3. Plant height increased from 2 to 8 WAP and treatment application resulted in significant differences. At 2 WAP, sweetcorn plants in plots that had received PM at an application rate of $30 \mathrm{t} / \mathrm{ha}^{-1}$ were significantly taller in both the early $(39.5 \mathrm{~cm})$ and late season $(42.3 \mathrm{~cm})$, while plants that did not receive PM or MLE (control plot) had the lowest height (27.9 and $30.7 \mathrm{~cm}$ in the early and late 
season, respectively). During early season planting there was no significant difference in plant height among plants that received $3 \%$ MLE + $15 \mathrm{t} / \mathrm{ha}^{-1} \mathrm{PM}, 6 \% \mathrm{MLE}+15 \mathrm{t} / \mathrm{ha}^{-1} \mathrm{PM}, 9 \% \mathrm{MLE}+15 \mathrm{t} / \mathrm{ha}^{-1} \mathrm{PM}$, and $15 \mathrm{t} / \mathrm{ha}^{-1} \mathrm{PM}$. Likewise, the control plot was statistically similar for plants that received 3, 6, and 9\% MLE. During the late season, there were no significant differences in plant height in plots that received $9 \% \mathrm{MLE}+15 \mathrm{t} / \mathrm{ha}^{-1} \mathrm{PM}, 15 \mathrm{t} / \mathrm{ha}^{-1} \mathrm{PM}$, and $30 \mathrm{t} / \mathrm{ha}^{-1} \mathrm{PM}$.

At 4 WAP, plants that had received $30 \mathrm{t} / \mathrm{ha}^{-1} \mathrm{PM}$ in the early season were significantly taller $(65.8 \mathrm{~cm})$ than those that received $3 \% \mathrm{MLE}+15 \mathrm{t} / \mathrm{ha}^{-1} \mathrm{PM}, 6 \% \mathrm{MLE}+15 \mathrm{t} / \mathrm{ha}^{-1} \mathrm{PM}, 9 \% \mathrm{MLE}+15 \mathrm{t} / \mathrm{ha}^{-1} \mathrm{PM}$, and $15 \mathrm{t} / \mathrm{ha}-{ }^{1} \mathrm{PM}$ and were statistically similar, with heights of $33.9,35.2,35.1$, and $35.5 \mathrm{~cm}$, respectively. However in the late season, there was no significant difference between plants that received $9 \% \mathrm{MLE}+15 \mathrm{t} / \mathrm{ha}^{-1} \mathrm{pm}, 15 \mathrm{t} / \mathrm{ha}^{-1} \mathrm{PM}$, and $30 \mathrm{t} / \mathrm{ha}^{-}$ 1 PM. Plants that received no additional materials had heights of 44.1 and $34.2 \mathrm{~cm}$ in the early and late season, respectively.

At 6 WAP, plants in plots that received $30 \mathrm{t} / \mathrm{ha}^{-1} \mathrm{PM}$ were significantly taller $(152.6 \mathrm{~cm})$ in the early season, but were statistically similar to plants that received $9 \% \mathrm{MLE}+15 \mathrm{t} / \mathrm{ha}^{-1} \mathrm{PM}(142.2 \mathrm{~cm})$ and $15 \mathrm{t} / \mathrm{ha}^{-1} \mathrm{PM}(138.1 \mathrm{~cm}) \mathrm{in}$ the late season. Sweetcorn plants in plots that received neither MLE nor PM had the lowest plant height, of 81.6 and $76.7 \mathrm{~cm}$ during the early and late season, respectively. This trend did not change at 8 WAP: sweetcorn plants in plots that received $30 \mathrm{t} / \mathrm{ha}^{-1} \mathrm{PM}$ were significantly taller $(193.6 \mathrm{~cm})$ in the early season but in the late season were not significantly taller than those that received $6 \% \mathrm{MLE}+15 \mathrm{t} / \mathrm{ha}^{-1} \mathrm{PM}, 9 \% \mathrm{MLE}+15 \mathrm{t} / \mathrm{ha}^{-1} \mathrm{PM}$, and $15 \mathrm{t} / \mathrm{ha}^{-1} \mathrm{PM}$, while crops that received neither MLE nor PM had the lowest height $(139$ and $92.8 \mathrm{~cm})$ for the early and late season, respectively.

The PM application rate of $30 \mathrm{t} / \mathrm{ha}^{-1}$ had a more significant effect on growth parameters than other rates of MLE and PM applied. This could be attributed to its special characteristics of faster mineralization than other organic manures, and rapid release of nutrients for plant uptake and utilization. This is similar to the findings of Izunobi (2002), who identified PM as the richest animal manure with the ability to enhance growth with respect to plant height, leaf area, and total chlorophyll content. It is also in agreement with the findings of Brady and Wells (2008), who reported that PM mineralizes faster and releases its nutrients more rapidly for growth enhancement. This is in agreement with the findings of Akanni and Ojeniyi (2008). Ayoola and Makinde (2009) and Uwah, Eneji, and Eshiet (2011) also observed that increased rates of PM application - 20-30 t/ ha $\mathrm{h}^{-1}$ - resulted in increased plant height, number of leaves, and leaf area in Amaranthus and maize crops. It is also consistent with the findings of Adeleye, Ayeni, and Ojeniyi (2010), who reported that PM application at $30 \mathrm{t} / \mathrm{ha}^{-1}$ increased the growth parameters of tomato including plant height, leaf area, and stem girth, which eventually influenced fruit yield positively.

Table 3. Effects of MLE and PM on plant height of sweetcorn $(\mathrm{cm})$.

\begin{tabular}{|c|c|c|c|c|c|c|c|c|}
\hline \multirow[b]{3}{*}{ Treatment } & \multicolumn{8}{|c|}{ Weeks after sowing (WAS) } \\
\hline & \multicolumn{2}{|l|}{$\boldsymbol{2}$} & \multicolumn{2}{|c|}{$4 \longrightarrow$} & \multicolumn{2}{|c|}{$6 \longrightarrow$} & \\
\hline & $\begin{array}{c}\text { Early } \\
\text { season }\end{array}$ & $\begin{array}{c}\text { Late } \\
\text { season }\end{array}$ & $\begin{array}{c}\text { Early } \\
\text { season }\end{array}$ & $\begin{array}{c}\text { Late } \\
\text { season }\end{array}$ & $\begin{array}{c}\text { Early } \\
\text { season }\end{array}$ & $\begin{array}{c}\text { Late } \\
\text { season }\end{array}$ & $\begin{array}{c}\text { Early } \\
\text { season }\end{array}$ & $\begin{array}{c}\text { Late } \\
\text { season }\end{array}$ \\
\hline Control $(0 \%)$ & $27.9^{\mathrm{c}}$ & $30.7^{b}$ & $44.1^{\mathrm{c}}$ & $34.2^{\mathrm{b}}$ & $81.6^{\mathrm{d}}$ & $76.7^{\mathrm{c}}$ & $139.0^{\mathrm{c}}$ & $92.8^{\mathrm{b}}$ \\
\hline $3 \% \mathrm{MLE}$ & $28.6^{\mathrm{c}}$ & $32.6^{\mathrm{b}}$ & $45.3^{\mathrm{c}}$ & $33.7^{b}$ & $84.4^{\mathrm{d}}$ & $84.4^{c}$ & $146.2^{\mathrm{c}}$ & $106.1^{b}$ \\
\hline $6 \% \mathrm{MLE}$ & $28.7^{\mathrm{c}}$ & $33.2^{\mathrm{b}}$ & $47.9^{\mathrm{c}}$ & $35.7^{b}$ & $95.6^{\mathrm{d}}$ & $94.2^{\mathrm{b}}$ & $153.6^{\mathrm{c}}$ & $109.7^{b}$ \\
\hline $9 \%$ MLE & $29.2^{\mathrm{c}}$ & $31.8^{\mathrm{b}}$ & $52.1^{b}$ & $39.1^{b}$ & $98.6^{\mathrm{d}}$ & $96.1^{b}$ & $162.6^{\mathrm{c}}$ & $118.6^{\mathrm{b}}$ \\
\hline $\begin{array}{l}3 \% \text { MLE }+15 \mathrm{t} / \mathrm{ha}^{-1} \\
\mathrm{PM}\end{array}$ & $33.9^{\mathrm{b}}$ & $33.1^{\mathrm{b}}$ & $55.9^{\mathrm{b}}$ & $39.8^{\mathrm{b}}$ & $111.7^{\mathrm{c}}$ & $107.2^{\mathrm{b}}$ & $166.3^{c}$ & $132.8^{\mathrm{b}}$ \\
\hline $\begin{array}{l}6 \% \text { MLE }+15 \mathrm{t} / \mathrm{ha}^{-1} \\
\mathrm{PM}\end{array}$ & $35.2^{\mathrm{b}}$ & $33.2^{\mathrm{b}}$ & $58.6^{\mathrm{b}}$ & $38.3^{\mathrm{b}}$ & $121.1^{\mathrm{c}}$ & $111.4^{\mathrm{b}}$ & $176.3^{\mathrm{c}}$ & $148.7^{\mathrm{a}}$ \\
\hline $\begin{array}{l}9 \% \text { MLE }+15 \mathrm{t} / \mathrm{ha}^{-1} \\
\mathrm{PM}\end{array}$ & $35.1^{\mathrm{b}}$ & $39.0^{\mathrm{a}}$ & $62.2^{\mathrm{b}}$ & $53.1^{\mathrm{a}}$ & $148.3^{\mathrm{b}}$ & $142.2^{\mathrm{a}}$ & $189.0^{\mathrm{b}}$ & $152.2^{\mathrm{a}}$ \\
\hline 15 tha $^{-1} \mathrm{PM}$ & $35.5^{\mathrm{b}}$ & $41.7^{\mathrm{a}}$ & $61.5^{\mathrm{b}}$ & $52.1^{\mathrm{a}}$ & $146.3^{\mathrm{b}}$ & $138.1^{\mathrm{a}}$ & $188.0^{\mathrm{b}}$ & $151.4^{\mathrm{a}}$ \\
\hline 30 tha $^{-1}$ PM & $39.5^{\mathrm{a}}$ & $42.3^{\mathrm{a}}$ & $65.8^{\mathrm{a}}$ & $53.4^{\mathrm{a}}$ & $152.6^{\mathrm{a}}$ & $144.2^{\mathrm{a}}$ & $193.6^{\mathrm{a}}$ & $152.8^{\mathrm{a}}$ \\
\hline
\end{tabular}

\subsection{Effects of MLE and PM on Leaf Number}

Table 4 shows the effects of treatments on leaf number at different WAP. In all treatments, the number of leaves consistently and significantly increased between 2 and 8 WAP.

At 2 WAP, sweetcorn plants that received PM at $30 \mathrm{t} / \mathrm{ha}^{-1}$ during the early season had significantly more leaves (4.6 per plant) than under all other treatments, while plants that received $3 \%$ MLE had the lowest number of leaves (3.8 per plant). Similar results were obtained during the late season: plants that received $30 \mathrm{t} / \mathrm{ha}^{-1} \mathrm{PM} \mathrm{had}$ significantly more leaves (4.6 per plant) while the remaining treatments were statistically similar except for those in the control plot.

At 4 WAP, sweetcorn that received PM at $30 \mathrm{t} / \mathrm{ha}^{-1}$ had significantly more leaves (8.1 per plant) in the early season while for all remaining treatments there were significantly more leaves than in the control plots (6.8 per plant). In the late season there was no significant difference in the number of leaves among sweetcorn plants in plots 
that received 9\% MLE, 3\% MLE + 15 t/ ha ${ }^{-1} \mathrm{PM}, 6 \%$ MLE + $15 \mathrm{t} / \mathrm{ha}^{-1} \mathrm{PM}, 9 \% \mathrm{MLE}+15 \mathrm{t} / \mathrm{ha}^{-1} \mathrm{PM}, 15 \mathrm{t} / \mathrm{ha}-^{1} \mathrm{PM}$, and $30 \mathrm{t} / \mathrm{ha}^{1} \mathrm{PM}$. Plants that received neither MLE nor PM in both planting seasons had the lowest number of leaves (5.7 and 6.8 per plant, respectively).

At $6 \mathrm{WAP}$, there were significant differences in the number of leaves among early-planted, but not among lateplanrd, plots. Early-planted sweetcorn that received $30 \mathrm{t} / \mathrm{ha}^{-1} \mathrm{PM}$ had the highest number of leaves (10.8 per plant), which was statistically similar to that in plots that received $9 \% \mathrm{MLE}+15 \mathrm{t} / \mathrm{ha}^{-1} \mathrm{PM}$ and $15 \mathrm{t} / \mathrm{ha}^{-1} \mathrm{PM}$, while the control plots had the lowest number of leaves (8.8 per plant). At $8 \mathrm{WAP}$, plants with $30 \mathrm{t} / \mathrm{ha}^{-1} \mathrm{PM}$ had the highest number of leaves in both experiments (10.1 and 13.1 per plant) while those in the control plot had the lowest number (9.5 and 10.2 per plant). In the early season, there were no significant differences among sweetcorn that received $9 \%$ MLE + $15 \mathrm{t} / \mathrm{ha}^{-1} \mathrm{PM}, 15 \mathrm{t} / \mathrm{ha}^{-1} \mathrm{PM}$, and $30 \mathrm{t} / \mathrm{ha}^{-1} \mathrm{PM}$.

Poultry manure application at $30 \mathrm{t} / \mathrm{ha}^{-1}$ was significantly better than other rates of MLE and PM. This was probably because that rate satisfied crop requirements in the agro-ecological environment where the experiment was conducted, coupled with the peculiar characteristics of PM such as increased carbon content, water-holding capacity, aggregation of soils, and availability of water-soluble exchangeable potassium and magnesium, while also reducing soil bulk density. This result is in tandem with the findings of Akanni and Ojeniyi (2008); Ayoola and Makinde (2009) and Akram, Athar, and Ashraf (2007), who attributed increases in number of leaves, plant height, stem diameter, and leaf area index of maize to the possibility that the rate satisfied the agro-ecological requirement of the experimental site, and that the essential nutrients supplied by PM are associated with increased photosynthetic activity. This is also consistent with the findings of Zaki and Rady (2015), who observed that MLE application increased the number of leaves, shoot length, leaf area per plant, and old dry leaf weight of Phaseolus vulgaris (common bean). It is also in agreement with the findings of Anyaegbu (2015), who reported that plant height in okra following application of $\mathrm{N} / \mathrm{P} / \mathrm{K}$ fertilizer was not significantly different from that in plants that received MLE, thus confirming the assertion of Foidle, Makkar, and Beckee (2001) that M. oleifera is a fertility-enhancing plant. It is also similar to the findings of Prabhu, Kumar, and Rajamani (2009), who reported that plant height and number of leaves per plant in kalmegh (Andrographis paniculata) were highest with $2 \%$ MLE compared to other sources of plant growth regulatory substances, which they attributed to the enhanced cell division and elongation of crops in response to the role of MLE as a plant growth-promoting substance - hence the positively higher fruit yield.

Table 4. Effects of MLE and PM on number of leaves per plant.

\begin{tabular}{|c|c|c|c|c|c|c|c|c|}
\hline \multirow[b]{3}{*}{ Treatment } & \multirow{2}{*}{\multicolumn{2}{|c|}{2}} & \multicolumn{6}{|c|}{ Weeks after sowing (WAS) } \\
\hline & & & \multicolumn{2}{|l|}{4} & \multicolumn{2}{|l|}{6} & \multicolumn{2}{|l|}{8} \\
\hline & $\begin{array}{l}\text { Early } \\
\text { season }\end{array}$ & $\begin{array}{c}\text { Late } \\
\text { season }\end{array}$ & $\begin{array}{c}\text { Early } \\
\text { season }\end{array}$ & $\begin{array}{c}\text { Late } \\
\text { season }\end{array}$ & $\begin{array}{c}\text { Early } \\
\text { season }\end{array}$ & $\begin{array}{c}\text { Late } \\
\text { season }\end{array}$ & $\begin{array}{c}\text { Early } \\
\text { season }\end{array}$ & $\begin{array}{c}\text { Late } \\
\text { season }\end{array}$ \\
\hline Control (O\%) & $4.0^{b}$ & $3.8^{\mathrm{c}}$ & $6.8^{\mathrm{c}}$ & $5.7^{\mathrm{b}}$ & $8.8^{\mathrm{b}}$ & $8.0^{\mathrm{a}}$ & $10.2^{b}$ & $9.5^{\mathrm{b}}$ \\
\hline $3 \% \mathrm{MLE}$ & $4.1^{b}$ & $4.0^{b}$ & $7.0^{\mathrm{b}}$ & $5.7^{\mathrm{b}}$ & $9.0^{\mathrm{b}}$ & $8.0^{\mathrm{a}}$ & $10.5^{b}$ & $10.0^{\mathrm{a}}$ \\
\hline $6 \% \mathrm{MLE}$ & $4.1^{b}$ & $4.0^{b}$ & $7.3^{\mathrm{b}}$ & $6.1^{\mathrm{b}}$ & $9.2^{\mathrm{b}}$ & $7.9^{\mathrm{a}}$ & $11.1^{b}$ & $10.0^{\mathrm{a}}$ \\
\hline $9 \% \mathrm{MLE}$ & $4.1^{\mathrm{b}}$ & $4.0^{b}$ & $7.5^{\mathrm{b}}$ & $7.3^{\mathrm{a}}$ & $9.3^{\mathrm{b}}$ & $8.0^{\mathrm{a}}$ & $11.4^{b}$ & $10.0^{\mathrm{a}}$ \\
\hline $\begin{array}{l}3 \% \text { MLE }+15 \mathrm{t} / \mathrm{ha}^{-1} \\
\mathrm{PM}\end{array}$ & $4.2^{\mathrm{b}}$ & $4.1^{\mathrm{b}}$ & $7.7^{\mathrm{b}}$ & $7.3^{\mathrm{a}}$ & $9.4^{\mathrm{b}}$ & $8.1^{\mathrm{a}}$ & $11.6^{\mathrm{b}}$ & $10.0^{\mathrm{a}}$ \\
\hline $\begin{array}{l}6 \% \text { MLE }+15 \mathrm{t} / \mathrm{ha}^{-1} \\
\mathrm{PM}\end{array}$ & $4.3^{\mathrm{b}}$ & $4.2^{\mathrm{b}}$ & $7.7^{\mathrm{b}}$ & $7.2^{\mathrm{a}}$ & $9.7^{\mathrm{b}}$ & $8.0^{\mathrm{a}}$ & $11.7^{\mathrm{b}}$ & $10.0^{\mathrm{a}}$ \\
\hline $\begin{array}{l}9 \% \text { MLE }+15 \mathrm{t} / \mathrm{ha}^{-1} \\
\mathrm{PM}\end{array}$ & $4.3^{\mathrm{b}}$ & $4.2^{\mathrm{b}}$ & $7.8^{\mathrm{b}}$ & $7.3^{\mathrm{a}}$ & $10.5^{\mathrm{a}}$ & $8.0^{\mathrm{a}}$ & $12.5^{\mathrm{a}}$ & $10.0^{\mathrm{a}}$ \\
\hline $15 \mathrm{t} / \mathrm{ha}^{-1} \mathrm{PM}$ & $4.3^{b}$ & $4.2^{\mathrm{b}}$ & $7.8^{\mathrm{b}}$ & $7.2^{\mathrm{a}}$ & $10.5^{\mathrm{a}}$ & $8.0^{\mathrm{a}}$ & $12.4^{\mathrm{a}}$ & $10.0^{\mathrm{a}}$ \\
\hline $30 \mathrm{t} / \mathrm{ha}^{-1} \mathrm{PM}$ & $4.6^{\mathrm{a}}$ & $4.6^{\mathrm{a}}$ & $8.1^{\mathrm{a}}$ & $7.38^{\mathrm{a}}$ & $10.8^{\mathrm{a}}$ & $8.1^{\mathrm{a}}$ & $13.1^{\mathrm{a}}$ & $10.2^{\mathrm{a}}$ \\
\hline
\end{tabular}

\subsection{Effects of MLE and PM on Stem Girth}

The response of stem girth to MLE and PM is shown in Table 5. Stem girth consistently increased from 2 to 8 WAP in both planting seasons. MLE and PM application caused significant differences in stem girth at 2 WAP. In the early season, sweetcorn plants that received $30 \mathrm{t} / \mathrm{ha}^{-1} \mathrm{PM}$ had the highest stem girth $(1.33 \mathrm{~cm})$ followed by crops with $15 \mathrm{t} / \mathrm{ha}^{-1} \mathrm{PM}(1.08 \mathrm{~cm})$. However, these were not significantly different from the other treatments except for the control plot, which showed significantly lower stem girth of $0.75 \mathrm{~cm}$. In the late season cropping, the application of $30 \mathrm{t} / \mathrm{ha}^{-1} \mathrm{PM}$ yielded the highest stem girth $(1.20 \mathrm{~cm})$ followed by sweetcorn that received $15 \mathrm{t} / \mathrm{ha}{ }^{-1} \mathrm{PM}(1.14 \mathrm{~cm})$, while the control plot recorded the lowest stem girth of $0.71 \mathrm{~cm}$ - not significantly different from plants that received 3 and $6 \%$ MLE.

At 4 WAP, results of all other treatments were significantly superior to those in the control plot, which had the lowest stem girth of $1.33 \mathrm{~cm}$ during the early season, while sweetcorn that received $30 \mathrm{t} / \mathrm{ha}^{-1} \mathrm{PM}$ had the highest stem girth $(2.50 \mathrm{~cm})$. A slight difference was observed during late season planting: plants with $30 \mathrm{t} / \mathrm{ha}^{-1} \mathrm{PM}$ yielded the highest stem girth $(2.02 \mathrm{~cm})$ but were statistically similar to plants that were administered $9 \%$ MLE, $3 \%$ MLE $+15 \mathrm{t} / \mathrm{ha}^{-1} \mathrm{PM}, 6 \% \mathrm{MLE}+15 \mathrm{t} / \mathrm{ha}^{-1} \mathrm{PM}, 9 \% \mathrm{MLE}+15 \mathrm{t} / \mathrm{ha}^{-1} \mathrm{PM}$, and $15 \mathrm{t} / \mathrm{ha}^{-1} \mathrm{PM}$. Plants in control plots had the lowest stem girth, $0.85 \mathrm{~cm}$. 
At 6 WAP, all treatments resulted in significantly higher stem girth than in the control plot. Plants administered $30 \mathrm{t} / \mathrm{ha}^{-1} \mathrm{PM}$ had the highest stem girth $(3.08 \mathrm{~cm})$ followed by those given $9 \% \mathrm{MLE}+15 \mathrm{t} / \mathrm{ha}^{-1} \mathrm{PM}(2.58 \mathrm{~cm})$ during the early season. However, plants in the control plots had the lowest stem girth $(1.67 \mathrm{~cm})$. This pattern was repeated in the late season planting, where the highest stem girth of $2.68 \mathrm{~cm}$ was recorded in plants administered 30 $\mathrm{t} / \mathrm{ha}^{-1} \mathrm{PM}$ - statistically similar to the other treatments except for the control plot. Crops in the control plot had the lowest stem girth, $1.56 \mathrm{~cm}$. At 8 WAP there were no significant differences among the various treatments in the early season. Sweetcorn plants administered $30 \mathrm{t} / \mathrm{ha}^{-1} \mathrm{PM}$ had the highest stem girth $(3.75 \mathrm{~cm})$ while those in the control plots had the lowest $(2.17 \mathrm{~cm})$. Similarly, there were no significant differences among the various treatments during late season planting, except for plants in the control plots that had the lowest stem girth $(2.12 \mathrm{~cm})$.

Sweetcorn crops treated with $30 \mathrm{t} / \mathrm{ha}^{-1} \mathrm{PM}$ had the highest stem girth at $8 \mathrm{WAP}$, statistically similar to plants that received $9 \% \mathrm{MLE}+15 \mathrm{t} / \mathrm{ha}^{-1} \mathrm{PM}$. This could be attributed to the presence of macro- and micronutrients in MLE and PM, fast mineralization, and ease of absorption, all of which promote the establishment, growth, and maturation of crops at all stages of their life cycle. This is similar to the findings of Foidle et al. (2001), who reported that an aqueous extract of $M$. oleifera influenced apical growth in both tomato and sorghum. The report further argued that MLE also gave significantly higher (100\%), vigorous, and good-quality tomato seedlings with respect to plant height, number of leaves, and time of flowering. This is in agreement with the findings of Anyaegbu, Iwuanyanwu, and Omaliko (2013), who observed that the application of various forms of MLE positively influenced the growth and development of fluted pumpkin (Telfaria occidentalis).

Table 5. Effect of MLE and PM on stem girth (cm).

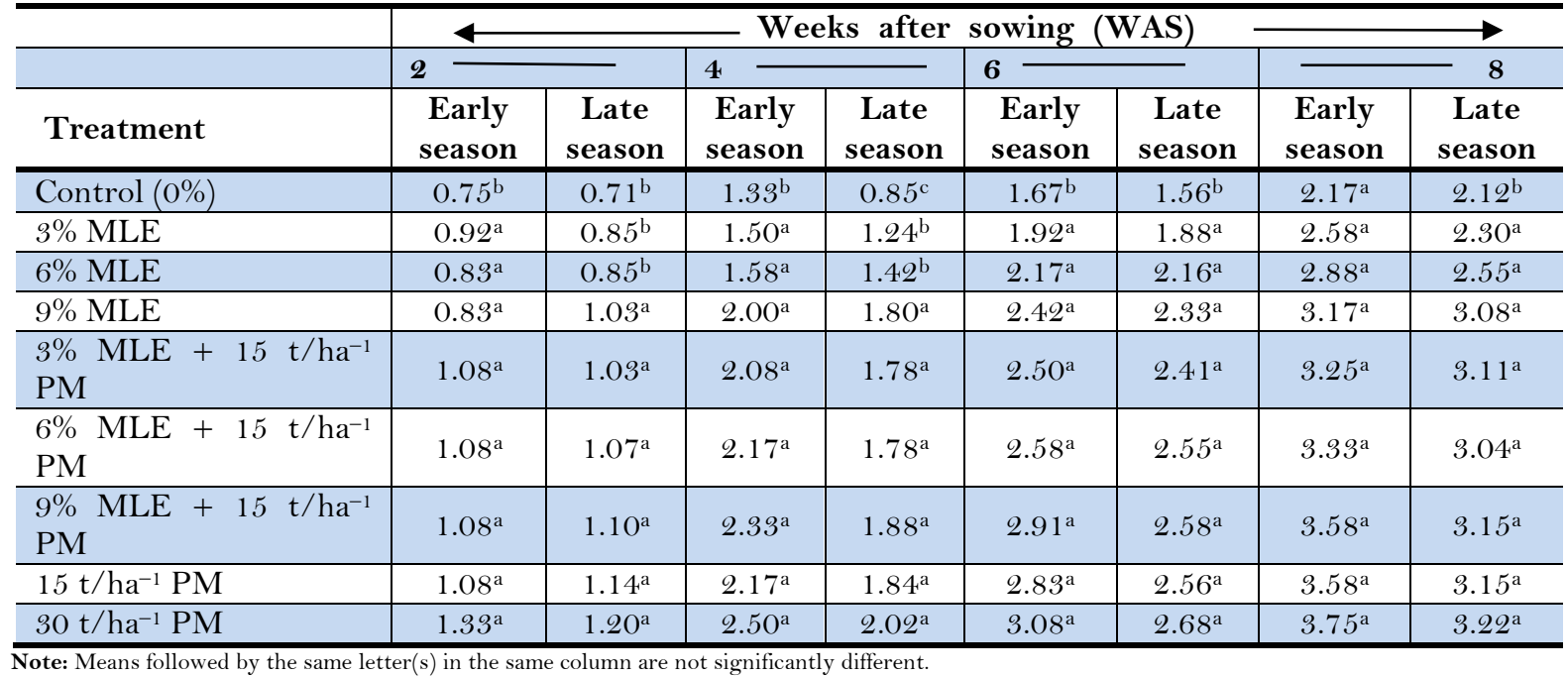

3.6. Effects of MLE and PM on Leaf Area

The response in regard to leaf area of MLE and PM is shown in Table 6. Leaf area gradually increased from 2 to 8 WAP in both planting seasons.

Significant differences were observed in leaf area of sweetcorn at 2 WAP in both early and late season plantings. For early season planting, plots that received $30 \mathrm{t} / \mathrm{ha}^{-1} \mathrm{PM}$ recorded the highest leaf area $\left(115.1 \mathrm{~cm}^{2}\right)$ but this was not significantly different from plants that received $15 \mathrm{t} / \mathrm{ha}^{-1} \mathrm{PM}, 9 \% \mathrm{MLE}+15 \mathrm{t} / \mathrm{ha}^{-1} \mathrm{PM}, 6 \% \mathrm{MLE}+15 \mathrm{t} / \mathrm{ha}^{-1}$ PM, or 3\% MLE + $15 \mathrm{t} / \mathrm{ha}^{-1}$ PM. Sweetcorn plants that received neither MLE nor PM had the lowest leaf area, 68.5 $\mathrm{cm}^{2}$. In late season, sweetcorn plants that received $30 \mathrm{t} / \mathrm{ha}^{-1} \mathrm{PM}$ had the highest leaf area $\left(88.3 \mathrm{~cm}^{2}\right)$, statistically similar to those that received 9\% MLE, 3\% MLE + $15 \mathrm{t} / \mathrm{ha}^{-1} \mathrm{PM}, 6 \% \mathrm{MLE}+15 \mathrm{t} / \mathrm{ha}^{-1} \mathrm{PM}, 9 \% \mathrm{MLE}+15 \mathrm{t} / \mathrm{ha}^{-1}$ $\mathrm{PM}$, and $15 \mathrm{t} / \mathrm{ha}^{-1} \mathrm{PM}$. The control plot, which received neither MLE nor PM, had the lowest leaf area $\left(65.3 \mathrm{~cm}^{2}\right)$ but this was not significantly different from plants that received $3 \% \operatorname{MLE}\left(65.8 \mathrm{~cm}^{2}\right)$ and $6 \% \operatorname{MLE}\left(68.9 \mathrm{~cm}^{2}\right)$.

At 4 WAP, sweetcorn plants that received $30 \mathrm{t} / \mathrm{ha}^{-1} \mathrm{PM}$ had the highest leaf area $\left(215.7\right.$ and $\left.185.1 \mathrm{~cm}^{2}\right)$, followed by those that received 9\% MLE $+15 \mathrm{t} / \mathrm{ha}^{-1} \mathrm{PM}\left(198.0 \mathrm{~cm}^{2}\right.$ and $\left.179.1 \mathrm{~cm}^{2}\right)$. Plants that received neither MLE nor PM had the lowest leaf area (117.4 and $110.1 \mathrm{~cm}^{2}$ during early and late season plantings, respectively). At 6 WAP, sweetcorn plants that received $30 \mathrm{t} / \mathrm{ha}^{-1} \mathrm{PM}$ had the highest leaf area $\left(451.3\right.$ and $\left.259.6 \mathrm{~cm}^{2}\right)$, followed closely by those that received $9 \%$ MLE $+15 \mathrm{t} / \mathrm{ha}^{-1}\left(434.8\right.$ and $\left.255.1 \mathrm{~cm}^{2}\right)$, while the control plot had the lowest leaf area (235.9 and $202.8 \mathrm{~cm}^{2}$ for the late and early season plantings, respectively). In the late season, however, there was no significant difference between the various treatments while in the early season, plants in the control plot and 3, 6, and $9 \%$ MLE were statistically similar, as were plants that received 3\% MLE + $15 \mathrm{t} / \mathrm{ha}^{-1} \mathrm{PM}, 6 \% \mathrm{MLE}+15 \mathrm{t} / \mathrm{ha}^{-1} \mathrm{PM}$, $9 \% \mathrm{MLE}+15 \mathrm{t} / \mathrm{ha}^{-1} \mathrm{PM}, 15 \mathrm{t} / \mathrm{ha}^{-1} \mathrm{PM}$ and $30 \mathrm{t} / \mathrm{ha}^{-1} \mathrm{PM}$.

At 8 WAP, sweetcorn that received $30 \mathrm{t} / \mathrm{ha}^{-1} \mathrm{PM}$ had the highest leaf area $\left(584.9\right.$ and $\left.402.9 \mathrm{~cm}^{2}\right)$ followed closely by plants that received 9\% MLE + $15 \mathrm{t} / \mathrm{ha}^{-1} \mathrm{PM}\left(546.2\right.$ and $\left.392.2 \mathrm{~cm}^{2}\right)$, though there was no significant difference Sweetcorn plants in the control plot had the lowest leaf area, 308.4 and $247 \mathrm{~cm}^{2}$. In the early season, there was no significant difference between plants treated with 3, 6, and 9\% MLE, or between those grown with $3 \%$ MLE + 15 t/ha hM, $^{-1} \% \mathrm{MLE}+15 \mathrm{t} / \mathrm{ha}^{-1} \mathrm{PM}, 9 \% \mathrm{MLE}+15 \mathrm{t} / \mathrm{ha}^{-1} \mathrm{PM}, 15 \mathrm{t} / \mathrm{ha}^{-1} \mathrm{PM}$, and $30 \mathrm{t} / \mathrm{ha}^{-1} \mathrm{PM}$. 


\subsection{Effects of MLE and PM on Leaf Area}

The results of the effects of MLE and PM on leaf area $\left(\mathrm{cm}^{2}\right)$ of sweetcorn are presented in Table 6. These indicate that at 2 WAP, MLE 3, 6, and 9\% were significantly different $\left(P \leq \_.05\right)$ from control in both early and late season croppings. At 4 WAP, control showed 117.4 and $110.0 \mathrm{~cm}^{2}$, significantly lower than PM at 15 and $30 \mathrm{t} / \mathrm{ha}^{-1}$ with leaf area of $178.3,215.7,171.8$, and $185.1 \mathrm{~cm}^{2}$ for both early and late season croppings. At 6 WAP there were no

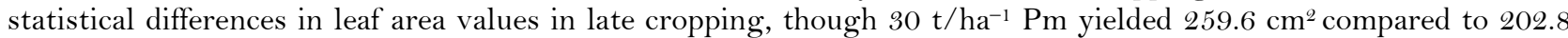
$\mathrm{cm}^{2}$ for control. Similarly, PM15 and $30 \mathrm{t} / \mathrm{ha}^{-1}$ yielded $429.5 \mathrm{~cm}$ and $457.3 \mathrm{~cm}^{2}$, significantly higher than control and MLE applied at different concentrations.

It was observed that there was a steady increase in leaf area as the weeks progressed. PM yielded the highest leaf area of $584.9 \mathrm{~cm}^{2}$ at $30 \mathrm{t} / \mathrm{ha}^{-1}$ followed by $528.6 \mathrm{~cm}^{2}$ at $15 \mathrm{t} / \mathrm{ha}^{-1}$, while in the control it was $308.4 \mathrm{~cm}^{2}$ in the early cropping. For late cropping, $247.0 \mathrm{~cm}^{2}$ was recorded for the control, which was significantly lower than for all other treatments.

The application rate of $30 \mathrm{t} / \mathrm{ha}^{-} \mathrm{PM}$ yielded better performance than other treatments at 8 WAP. This could be attributed to the increased quantity and availability of macro- and micronutrients in PM, its rapid mineralization, and ease of absorption, which enhanced crop growth and development. This is similar to the findings of Muhamman and Kwada (2015), who reported that aqueous foliar application of MLE had a higher (and significant) effect on all growth parameters of pawpaw seedlings than the application of coconut milk. It is also in agreement with the findings of Muhamman and Mohammed (2014), Chattha et al. (2015), Anyaegbu (2014), and Anyaegbu (2015), who reported growth and yield increases in various crops, including maize, okra, and garden egg, as a result of foliar application of MLE.

Table 6. Effects of MLE and PM on Leaf Area $\left(\mathrm{cm}^{2}\right)$.

\begin{tabular}{|c|c|c|c|c|c|c|c|c|}
\hline \multirow[b]{3}{*}{ Treatment } & \multicolumn{6}{|c|}{$\longleftarrow$ Weeks after sowing (WAS) } & \multicolumn{2}{|c|}{$\longrightarrow$} \\
\hline & \multicolumn{2}{|l|}{2} & \multicolumn{2}{|c|}{4} & & \multicolumn{2}{|l|}{-8} \\
\hline & $\begin{array}{c}\text { Early } \\
\text { season }\end{array}$ & $\begin{array}{c}\text { Late } \\
\text { season }\end{array}$ & $\begin{array}{c}\text { Early } \\
\text { season }\end{array}$ & $\begin{array}{c}\text { Late } \\
\text { season }\end{array}$ & $\begin{array}{c}\text { Early } \\
\text { season }\end{array}$ & $\begin{array}{c}\text { Late } \\
\text { season }\end{array}$ & $\begin{array}{c}\text { Early } \\
\text { season }\end{array}$ & $\begin{array}{c}\text { Late } \\
\text { season }\end{array}$ \\
\hline Control $(\mathrm{O} \%)$ & $68.5^{\mathrm{b}}$ & $65.3^{\mathrm{b}}$ & $117.4^{\mathrm{c}}$ & $110.1^{b}$ & $235.9^{\mathrm{b}}$ & $202.8^{\mathrm{a}}$ & $308.4^{c}$ & $247.0^{b}$ \\
\hline $3 \% \mathrm{MLE}$ & $70.1^{b}$ & $65.8^{\mathrm{b}}$ & $137.7^{\mathrm{b}}$ & $120.8^{\mathrm{b}}$ & $268.1^{\mathrm{b}}$ & $203.3^{\mathrm{a}}$ & $355.9^{\mathrm{b}}$ & $307.8^{\mathrm{a}}$ \\
\hline $6 \%$ MLE & $70.9^{\mathrm{b}}$ & $68.9^{\mathrm{b}}$ & $148.0^{\mathrm{b}}$ & $130.2^{\mathrm{b}}$ & $280.0^{\mathrm{b}}$ & $214.2^{\mathrm{a}}$ & $378.0^{\mathrm{b}}$ & $322.2^{\mathrm{a}}$ \\
\hline $9 \%$ MLE & $70.0^{\mathrm{b}}$ & $79.6^{\mathrm{a}}$ & $163.5^{\mathrm{b}}$ & $170.3^{\mathrm{a}}$ & $305.8^{\mathrm{b}}$ & $216.0^{\mathrm{a}}$ & $395.5^{\mathrm{b}}$ & $323.3^{\mathrm{a}}$ \\
\hline $3 \% \mathrm{MLE}+15 \mathrm{t} / \mathrm{ha}^{-1} \mathrm{PM}$ & $106.7^{\mathrm{a}}$ & $77.8^{\mathrm{a}}$ & $173.9^{\mathrm{b}}$ & $165.6^{\mathrm{a}}$ & $386.2^{\mathrm{a}}$ & $226.7^{\mathrm{a}}$ & $440.2^{\mathrm{a}}$ & $312.2^{\mathrm{a}}$ \\
\hline $6 \% \mathrm{MLE}+15 \mathrm{t} / \mathrm{ha}^{-1} \mathrm{PM}$ & $107.0^{\mathrm{a}}$ & $74.9^{\mathrm{a}}$ & $190.3^{\mathrm{a}}$ & $169.2^{\mathrm{a}}$ & $399.9^{a}$ & $228.0^{\mathrm{a}}$ & $484.4^{\mathrm{a}}$ & $315.6^{\mathrm{a}}$ \\
\hline $9 \% \mathrm{MLE}+15 \mathrm{t} / \mathrm{ha}^{-1} \mathrm{PM}$ & $107.0^{\mathrm{a}}$ & $81.8^{\mathrm{a}}$ & $198.0^{\mathrm{a}}$ & $179.1^{\mathrm{a}}$ & $434.8^{\mathrm{a}}$ & $255.1^{\mathrm{a}}$ & $546.2^{\mathrm{a}}$ & $392.2^{\mathrm{a}}$ \\
\hline $15 \mathrm{t} / \mathrm{ha}^{-1} \mathrm{PM}$ & $107.0^{\mathrm{a}}$ & $82.4^{\mathrm{a}}$ & $198.3^{\mathrm{a}}$ & $171.8^{\mathrm{a}}$ & $429.5^{\mathrm{a}}$ & $245.3^{\mathrm{a}}$ & $528.6^{\mathrm{a}}$ & $347.8^{\mathrm{a}}$ \\
\hline $30 \mathrm{t} / \mathrm{ha}^{-1} \mathrm{PM}$ & $115.1^{\mathrm{a}}$ & $88.3^{\mathrm{a}}$ & $215.7^{\mathrm{a}}$ & $185.1^{\mathrm{a}}$ & $451.3^{\mathrm{a}}$ & $259.6_{\mathrm{a}}$ & $584.9^{\mathrm{a}}$ & $402.9^{\mathrm{a}}$ \\
\hline
\end{tabular}

\subsection{Agronomic and Agricultural Extension Implications of the Study}

The findings listed below from the study are most valuable when the information contained is simplified and disseminated to farmers as new innovations by extension workers. The study provides the extension worker with the following:

i. Knowledge of improved sources of seed inputs.

ii. Awareness of best type of soil for cultivation of sweetcorn for optimal growth performance.

iii. Chemical composition of MLE and PM.

iv. Information on accurate quantities for MLE and PM usage.

v. Facts on time of application for MLE and PM.

\section{CONCLUSION AND RECOMMENDATIONS}

The results of this study indicate that the use of PM and MLE, either singly or in combination, is capable of positively influencing the growth of sweetcorn in the study area. Although variations were observed in the effectiveness of various concentrations of MLE, the results reveal the effectiveness of the application of moringa in boosting the growth of sweetcorn. The recommended application rates for optimum vegetative growth are:

i. Use of $30 \mathrm{t} / \mathrm{ha}^{-1} \mathrm{PM}$, which resulted in significantly better growth of sweetcorn compared to the other treatment applications evaluated.

ii. Use of a combination of $9 \% \mathrm{MLE}+15 \mathrm{t} / \mathrm{ha}^{-1} \mathrm{PM}$ as an alternative treatment.

iii. Use of $9 \%$ MLE as a sole application, which performed significantly better than both control and the other rates of MLE application. 
Funding: This study received no specific financial support.

Competing Interests: The authors declare that they have no competing interests.

Contributors/Acknowledgement: All authors participated equally in the design and performance of the current research.

Views and opinions expressed in this study are those of the authors views; the Asian Journal of Agriculture and Rural Development shall not be responsible or answerable for any loss, damage, or liability, etc. caused in relation to/arising out of the use of the content.

\section{REFERENCES}

Adeleye, E., Ayeni, L., \& Ojeniyi, S. (2010). Effect of poultry manure on soil physico-chemical properties, leaf nutrient contents and yield of yam (Dioscorea rotundata) on alfisol in southwestern Nigeria. Journal of American Science, 6(10), 871-878.

Akanni, D., \& Ojeniyi, S. (2008). Residual effect of goat and poultry manures on soil properties, nutrient content and yield of Amaranthus in Southwest Nigeria. Research Journal of Agronomy, 2(2), 44-47.

Akram, M. S., Athar, H., \& Ashraf, M. (2007). Improving growth and yield of sunflower (Helianthus annuus L.) by foliar application of potassium hydroxide (KOH) under salt stress. Pakistan Journal of Botany, 39(3), 769-776.

Amujoyegbe, B. J., Opabode, J. J., \& Olayinka, A. (2007). Effect of organic and inorganic fertilizer on yield and cholorophyll content of maize (Zea mays L) and sorghum (sorghum bicolor 1. (Moench). African Journal of Biotechnology, 6(16), 18691873.

Anyaegbu, P. O. (2014). Comparative assessment of effect of Moringa extracts, NPK fertilizer and poultry manure on soil properties and growth performance of Solanum melongena in Abuja, North Central region of Nigeria. Journal of Agricultural and Crop Research, 2(5), 88- 93.

Anyaegbu, P. O., Iwuanyanwu, U. P., \& Omaliko, C. P. E. (2013). Comparative evaluation of effects of Moringa oleifera extracts and different fertilizers on the performance of Telfaria occidentalis. International Journal of Applied Research and Technology, 2(11), 127-134.

Anyaegbu, P. O. (2015). Comparative evaluation of effects of leaf extracts of selected fallow species and NPK (15-15-15) fertilizer on the performance of Okra (Abelmoschus esculentus ) in Abuja, Nigeria. Report and Opinion, 7(10), 39- 46.

Ayoola, O., \& Makinde, E. (2009). Maize growth, yield and soil nutrient changes with N-enriched organic fertilizers. African Journal of Food, Agriculture, Nutrition and Development, 9(1), 580-592.Available at: https://doi.org/10.4314/ajfand.v9i1.19214.

Bingham, F. T. (1982). Method of soil analysis (pp. 431 - 447). USA: WI: American Society of Agronomy.

Brady, C., \& Wells, R. R. (2008). Nature and properties of soil (14th ed., pp. 74-114). New Delhi: Prentice Hall.

Breminer, J. M., \& Mulvaney, C. S. (1982). Nitrogen- Total. In : Methods of Soil analysis. Part 2: Chemical and microbiological properties. Page, A.; Miller, R.H. and Keeney, D.R. (Eds.) (pp. 595-624). Madison, Wisconsin ,USA: American Society of Agronomy-Soil Science Society of America.

Chapman, H. (1965). Cation-exchange capacity. Methods of Soil Analysis: Part 2 Chemical and Microbiological Properties, 9, 891-901.

Chattha, M. U., Sana, M. A., Munir, H., Ashraf, U., Ihtisham, U., \& Ibni-Zamir, S. (2015). Exogenous application of plant growth promoting substances enhances the growth, yield and quality of maize (Zea mays L.). Plant Knowledge Journal, 4(1), 1- 6.

DIPA. (2006). Handbook of Agriculture: facts and figures for farmers, students and all interested in farming. Director of Information and Publications of Agriculture (pp. 435). New Delhi: Indian Council of Agricultural Research.

Enujeke, E. C. (2013). Effects of poultry manure on growth and yield of improved maize in Asaba area of Delta State, Nigeria. IOSR Journal of Agriculture and Veterinary Science, 4(5), 24-30.

Foidle, N., Makkar, H. P. S., \& Beckee, K. (2001). The potential of Moringa oleifera for agricultural and Industrial uses. In: L. Fughe (ed.) The miracle tree: The multiple attributes of moringa (pp. $45-76$ ). Wageningen, the Netherlands: CTA Publications.

Gee, G. W., \& Baudee, J. W. (1986). Particle size analysis. In : Methods of soil analysis ; Part A. Klute, A. (Ed.) (Vol. 9, pp. 38341 1). Madison, Wisconsin: American Society of Agronomy-Soil Science Society of America.

IITA International Institute of Tropical Agriculture. (1979). Selected methods for soil and plant analysis. Juo, A.S.R.(Ed.) (pp. 57). Ibadan, Nigeria: IITA Manual Series 1.

Izunobi, N. D. (2002). Poultry husbandry: An integrated approach for tertiary students, extension agents, policy makers and farmers (Vol. 192, pp. 4-15). Ihiala, Nigeria: NADS Publishers.

Makkar, H. P. S., Francis, G., \& Becker, K. (2007). Bioactivity of phytochemicals in some lesser known plants and their effects and potential applications in livestock and aquaculture production systems. Animal 1(9), $1371-1391$.

Mishra, S. P., Singh, P., Singh, S., Das, R., \& Prasad, R. S. (2013). Moringa oleifera leaf extract as biostimulant for increasing pea yield. Indian Forester, 139(6), $562-563$.

Muhamman, M. A., \& Mohammed, S. G. (2014). Effects of aqueous extract of Moringa (Moringa oleifera LAM.) and nitrogenous rates on the contribution of some physiological and yield attributes to grain yield of Sesame (Sesamum indicum L.). Scientific papers. Series A. Agronomy, 57, 272- 275.

Muhamman, M. A., \& Kwada, B. (2015). Comparative efficacy of aqueous extract of Moringa (Moringa oleifera Lam) and Coconut (Cocos nucifera L.) milk on the performance of Pawpaw (Carica papaya L.) seedlings. International Journal of Advances in Agricultural \& Environmental Engineering, 2(1), 1- 3.

Nelson, D. W., \& Sommers, I. E. (1982). Organic carbon. In Miller, R. H. and Keeney, D. R. (ed.) Methods of Soil Analysis. Madison, W.I. USA: Part 2 Agronomy, Monograph 9 ASA and SSSA.

Okonmah, L. U., \& Eruotor, P. G. (2012). Arable crop production (pp. 283). Benin: Ethiope Publishing Co.

Phiri, C. (2010). Influence of Moringa oleifera leaf extracts on germination and early seedling development of major cereals. Agriculture and Biology Journal of North America, 1(5), $774 \quad$ - 777 .Available at: https://doi.org/10.5251/abjna.2010.1.5.774.777.

Phiri., C., \& Mbewe, D. (2010). Influence of Moringa oleifera leaf extracts on germination and seedling survival of three common legumes. International Journal of Agriculture and Biology, 12(2), 315-317.Available at: https://doi.org/10.5251/abjna.2010.1.5.774.777. 
Prabhu, M., Kumar, A. R., \& Rajamani, K. (2009). Influence of bio-stimulants on growth, yield and economics of kalmegh Andrographis paniculata. Madras Agricultural Journal, 96(1-6), 150-155.

Price, L. M. (2007). The moringa tree (pp. 7). ECHO Technical Note, North Fort Myers, Florida.

Roades, J. D. (1982). Salinity : Electrical conductivity and total dissolved solids. In : Methods of Soil Analysis, Part 3- Chemical methods . Page, A.; Miller, R.H. and Keeney, D.R. (Eds.) (pp. 417-436). Madison, Wisconsin, USA: American Society of Agronomy-Soil Science Society of America.

Ryan, J., Estefan, G., \& Rashid, A. (2001). Soil and plant analysis: Laboratory manual. Paper presented at the 2nd Ed. International Centre for Agricultural Research in the Dry Areas. Aleppo, Syria and the National. Agriculture Research Centre, Islamabad, Scientific Publishers (India).

Uwah, D. F., Eneji, A. E., \& Eshiet, U. J. (2011). Organic and mineral fertilizers effects on the performance of sweet maize (Zea mays L. saccharata Strut) in south eastern rainforest zone of Nigeria. International Journal of Agricultural Science, 3(1), 5461.

Yasmeen, A., Basra, S. M. A., Ahmad, R., \& Wahid, A. (2012). Performance of late sown wheat in response to foliar application of Moringa oleifera Lam. Leaf extract. Chilean Journal of Agricultural Research, 72(1), 92- 97.

Zaki, S. S., \& Rady, M. M. (2015). Moringa oleifera leaf extract improves growth, physiochemical attributes, antioxidant defence system and yields of salt-stressed Phaseolus vulgaris L. plants. International Journal of Chemical Technology Research, $8(11), 120-134$ 